\title{
Market Chain Analysis of HighValue Fruits in Bench Maji Zone, Southwest Ethiopia
}

\author{
Getahun Kassa ${ }^{1}$, Eskinder Yigezu ${ }^{2} \&$ Desalegn Alemayehu ${ }^{3}$ \\ ${ }^{1 \& 2}$ Department of Agricultural Economics, Mizan-Tepi University, P. O. Box 260, MizanTeferi, Ethiopia \\ ${ }^{3}$ Department of Horticulture, Mizan-Tepi University, P. O. Box 260, MizanTeferi, Ethiopia \\ Correspondence: Getahun Kassa, Department of Agricultural Economics, Mizan-Tepi University, P. O. Box 260, \\ MizanTeferi, Ethiopia. Tel: 251-913-182-408. E-mail: zgetah@gmail.com
}

Received: November 4, 2016 Accepted: April 5, 2017 Online Published: May 29, 2017

doi:10.5539/ijms.v9n3p124 URL: http://doi.org/10.5539/ijms.v9n3p124

\begin{abstract}
This research aimed at assessing the market chain of banana, avocado and mango fruits in Bench Maji zone. Both primary and secondary data were collected from 2 purposively selected fruits producing districts namely North Bench and South Bench districts. Primary data were collected through semi-structured questionnaire and focus group discussion. A total of 150 households were selected by using systematic random sampling technique. In addition, 40 traders were selected by using simple random sampling technique. Market structure - conduct performance analysis model was used to assess the performance of the fruits market. The result revealed that the participants in the fruits market were identified as primary actors and secondary actors. Primary actors in the fruits market chain were producers, brokers/ agents, farmer traders, collectors, and wholesalers. Whereas, local tax authority, local police, transporters, and district Trade and Industry office were identified as secondary actors. Fruits market in the area was characterized by non-competitive nature with concentration ratio ranging from 42 to $91.10 \%$ indicating the existence of oligopoly market structure. Entrance and exit in the fruits market was blocked by licensing and access to channel. A channel that links producers to local wholesalers through brokers was more efficient in terms of large volumes of sales. However, performance of the fruits market was affected by seasonality, the existence of few big traders, limited access to information, absence of organized market center and brokers' interference. Therefore, attention has to be given to alleviate the problems so as to improve the performance of the fruits market.
\end{abstract}

Keywords: market chain, oligopoly, market concentration ratio and market performance

\section{Introduction}

\subsection{Background and Justification}

Trade in fruit and vegetable products in Ethiopia has been attractive in the face of highly volatile or declining long-term trends in prices for many traditional export products (NBE, 2013). Particularly, given the declining export earnings from traditional exports of coffee, horticulture products like fruits and vegetables are one of the main possible sources of foreign exchange for the country (World Bank, 2004). There is good opportunity for small scale growers to increase the exports of fresh fruits and vegetables to the neighboring countries such as Djibouti, Sudan and Somalia (NBE, 2013). Fruits and vegetables also have a large domestic market (EIA, 2012). Thus, fruit and vegetables are a priority sector for the government of Ethiopia, which aims to increase production by $47 \%$ between 2015 and 2020 (GTPII, 2015).

The production of horticultural crops, however, is much less developed than the production of food grains in the country (EIA, 2012). Lack of concerted public support, scanty information, poor understanding of how the market chain works, and lack of systematic documented knowledge are main threats that hampered the benefit of the sector (World Bank Group, 2006). Now a day, the demand for local fruits with higher quality like mango, papaya, apple and avocado are emerging (Humble \& Reneby, 2014). Though there is a growing demand for fruits in recent years because of growing population and changing dietary habits (ILRI, 2011), the contribution of fruits both to the diet and income of Ethiopian is insignificant (Simegnew, 2012). Consequently, the growing demand for fruits can only be satisfied if there is an efficient market that can create better incentive for the producers. Without having efficient and well-functioning market, the possible increment in output, incomes, and 
foreign exchange earnings could not be realized.

Marketing is the most significant energetic force of economic development and contains a guiding and simulating impact on production and distribution of agricultural products. The agricultural marketing system needs to bring an improvement in income and livelihood of agrarian societies. According to FAO (2005), in developing countries, most permanent crops produced by smallholder farmers and their product were marketed by the non-public entrepreneurs who operates as marketing chain, and distribute the products to terminal markets. Although the marketing chain is well known, smallholder farmers specifically face high cost in accessing markets and market information.

In a country like Ethiopia, which is frequently stricken by drought and famine, producing and marketing of fruit products generates income which can act as an economic buffer and seasonal safetynet for poor farm households (Takele, 2014). This is because marketing enables the agricultural producer to move from semi-subsistence to growing produce regularly for sale. However, if market performance is inefficient, the sustainability of the production becomes questionable and as a result a continuous supply of the commodity for the market becomes difficult (Nega, Teshale, \& Zebene, 2015). In the study area, though fruits are among the commercially important agricultural commodities for increasing income and improving livelihood of smallholder farmers, the marketing and market chain aspects of the fruits sub-sector have not yet been studied. This paper, therefore, intends to analyze the current chain of market for commercially high value fruits such as Banana, Mango, and Avocado in Bench Maji zone.

\section{Materials and Methods}

\subsection{Description of the Study Area}

The present study was carried out in Bench Maji zone of South Nations Nationalities and Peoples Regions (SNPPR) which is located $561 \mathrm{kms}$ southwest of the capital city Addis Ababa. The zone has 10 districts. The altitude of the zone varies between 700-2500 meters above sea level. The mean annual rainfall and temperature varies between $400-2000 \mathrm{~mm}$ and $15-27^{\circ} \mathrm{C}$ respectively. According to land utilization date of the region, $7.65 \%$ is cultivated land, $6.37 \%$ grazing land, $8.29 \%$ forest, bushes and shrub land, $69.88 \%$ cultivatable and $7.89 \%$ is covered by others (SNNP Investment Office, 2007).

\subsection{Sources of Data}

In order to address the objectives of the study, both primary and secondary data were used. The primary data were collected through semi-structured questionnaires and focus group discussion. Two types of interview schedules were prepared (one for farmers and the other for traders). Two types of focus group discussion were held with a member of 5 producers and 5 traders in a group whom are selected based on their knowledge and experience about fruits production and marketing.

\subsection{Method of Sampling and Sample Size}

Multistage - stage sampling techniques were used to select sample fruit producer farmers. In the first stage, North Bench and South Bench districts were selected purposively based on the level of fruit production and access to marketing. In the second stage, 2 kebeles from North Bench district (Yali and Gacheb) and 3 kebeles (Fanika, Janchu, and Kite) from South Bench district were selected purposively. During the selection process, the Kebeles potential for fruit production and the accessibility to market were taken into consideration. In the third stage, three villages from each Kebeles were selected by using stratified random sampling techniques. In the fourth stage, since there was no document about the number of fruits producers in the Kebeles and homogeneity of fruit producers, 30 producers from each Kebeles were selected. Thus, a total of 150 households were selected using systematic random sampling technique. Finally, 18 wholesalers, 5 agents/brokers, 2 collector cooperatives and 15 farmer traders were selected randomly. Over all, a total of 190 respondents were selected.

\subsection{Data Analysis}

Two types of analysis techniques, namely descriptive statistics tools (like mean, standard deviation, percentage, and table) and Market structure, conduct and performance analysis were used. Data were analyzed by using SPSS version 21 and Microsoft Excel 2007.

\subsubsection{Market Structure, Conduct and Performance Analysis (S-C-P)}

Efficiency factors can be evaluated by examining marketing enterprises for structure, conduct and performance (Abbott \& Makeham, 1981). The structure - conduct - performance (SCP) analysis involves the collection of both primary and secondary data (WFP, 2011). 
(a) Market Structure: refers to a set of market characteristics that determine the economic environment in which a firm operates (Thomas \& Maurice, 2011). The structure of the market is determined by computing the market concentration of firms in the market.

\section{Market concentration:}

According to Tomek \& Robinson (1990), concentration ratio refers to the number, and relative size of buyers in the market. The structure performance hypothesis states that the degree of market concentration is inversely related to the degree of competition (Edwards et al., 2005).

The concentration ratio is given as:

$\mathrm{C}=\sum_{i=1}^{\mathrm{r}} \mathrm{Si} \mathrm{i}=1,2,3,4 \ldots . \mathrm{r}$

Where, $\mathrm{C}=$ concentration ratio

$\mathrm{Si}=$ the percentage market share of the $\mathrm{i}^{\text {th }}$ firm

$\mathrm{r}=$ the number of relatively larger firms for which the ratio is going to be calculated

Concentration ratio of $50 \%$ or more is an indication of a strongly oligopolistic industry, $33-50 \%$ a weak oligopoly and less than that a competitive industry (Uhl \& Kohi, 1985).

(b) Market conduct: it is a systematic way to detect indication of unfair price setting practices and the conditions under which practices are likely to prevail. Meijer (1994) said that, "conduct is pattern of behavior which enterprises follow in adopting or adjusting to the market in which they sell or buy", in other words the strategies of the actors operating in the market.

\section{(c) Market performance (Marketing margin)}

Market performance is concerned with the benefits an industry generates for its different stakeholders (Stead et al., 1996). Measures of market performance reveal whether there is market power in an industry (Perloff, 2007). To evaluate market performance marketing margins analysis and sales volumes were analyzed. The total marketing margin is given by the formula shown below:

$\mathrm{TGMM}=\frac{\text { Consumer } \text { price }- \text { Farmers price }}{\text { Consumer } \text { price }} \times 100$

Where TGMM - Total gross marketing margin

Computing the total gross marketing margin (TGMM) is always related to the final price paid by the end buyer and is expressed as a percentage (Mendoza \& Rosegant, 1995). Wider marketing margin indicates high price to consumers and low price to producers and it is an indicator of the existence of imperfect markets (Cramer \& Jenson, 1982).

The producers' margin (which is the portion of the price paid by the consumer that goes to the producer) is calculated as:

GMMp $=1-$ TGMM

Where: GMMp is producers' share in consumer price.

The above equation tells us that a higher marketing margin diminishes producers' share and vice versa. It also provides an indication of welfare distribution among production and marketing agents.

\section{Result and Discussion}

\subsection{Socio-economic Characteristics of the Respondents}

Out of the total respondents, 95.97 percent of them were male and 4.03 percent of them were female. This implies that fruit production in the area is highly dominated by male headed households. Regarding marital status of the respondents, 4.70 percent of them were single, 91.95 percent of them were married, and the remaining 3.35 percent of them were widow. Having more than 90 percent of married respondents implies that fruit production plays greater contribution for household income and livelihood in the area. Regarding educational attainment of the respondents, 21.48 percent of them were unable to read and write, 69.80 percent of them were attended from grade 1 up to 6 , and the remaining 8.72 percent of them were attended from grade 7 upto 10. This implies that the majority of the respondents attended basic education. 
Table 1. Demographic information of the respondents

\begin{tabular}{llll}
\hline Description & & Number & Percentage \\
\hline Sex & Male & 143 & 95.97 \\
& Female & 6 & 4.03 \\
\hline Marital status & Single & 7 & 4.70 \\
& Married & 137 & 91.95 \\
& Widow & 5 & 3.35 \\
\hline Educational Attainment & Unable to read and write & 32 & 21.48 \\
& $1-6$ & 104 & 69.80 \\
& $7-10$ & 13 & 8.72 \\
\hline
\end{tabular}

Source: Own Survey (2016).

Regarding age of respondents, the mean age of the respondents (Table 2) was 35.27 years old. Out of the total respondents, 40.27 percent of them lied in the age range of 20-30 years old, 32.21 percent of them were lied in the age range of 31-40 years old, 22.82 percent of them lied in the age range of 41-50 years old, and the remaining 4.70 percent of them lied in the age range of above 50 years old. The average family size in the area was 6.12. Regarding the experience of the respondents in fruit production, the mean work experience was 8years. The mean land holding in the area was 1.18 ha per head. Out of the total respondents, 83.89 percent of them have a holding of less than 2 hectares per head and the remaining 16.11 percent of them have a holding of more than 2 hectares per head. This implies that the majority of the respondents are smallholder farmers.

Table 2. Household and farm characteristics of the respondents

\begin{tabular}{lll}
\hline Items & Mean & Standard Deviation \\
\hline Age (years) & 35.27 & 8.74 \\
Family size & 6.12 & 2.25 \\
Experience (years) & 8 & 5.21 \\
Landholding (ha) & 1.18 & 1.01 \\
\hline
\end{tabular}

Source: Own Survey (2016).

\subsection{Structures, Conduct and Performance (S-C-P) of Fruits Market Chains}

\subsubsection{Market Structure}

Market structure analysis covers other market actors outside of farming households such as importers/ exporters, wholesalers, retailers, assembler/ collectors, transporters and laborers (WFP, 2011).

\subsubsection{Major Actors in the Fruit Market Chain}

The actors in the fruits market chain in the area were classified into two categories as primary actors and secondary actors. Primary actors in this research included those that have direct influence from production to final consumption, whereas, secondary actors were those individuals and organizations which indirectly influence the fruit market chain.

The primary actors and their role are specified as follows:

a) Producers: - they are the first actors in the fruits market chain who are engaged in producing and supplying fruit products.

b) Farmer traders: - these are generally seasonal traders who actively participate in times of high supply of fruits products. The main objective of farmer traders is to handle certain volumes of fruits products for supplying to local consumers. The excess supply of fruits in the area in certain seasons is the triggering factor for them to be engaged in the fruits markets. Farmer traders do not possess a license to participate in the fruits markets. They distribute very small volumes of fruits products to the local market in peak seasons. They will return to farming as soon as the supply of fruits vanishes.

c) Agents /brokers: - these are individuals whose role in the fruits market chain is to purchase fruits from producers on behalf of wholesalers. They are given full delegation by licensed wholesalers to participate in fruits marketing process.

d) Collector cooperatives: - these are an association of unemployed rural youths formed with the entitlement of collecting fruit products from producers and supply it to local wholesalers. They are not entitled to distribute fruit products out of the locality. 
e) Local wholesalers: - these are individuals who are licensed to purchase fruits from producers, brokers, or collector cooperatives and supply it to big cities in Ethiopia.

f) Local consumers: - these are considered as one of the actors in the local fruits market chain. They buy fruit products from farmer traders to satisfy their consumption demand.

Other primary actors identified situated in terminal markets were big wholesalers, retailers, processors and consumers.

The secondary actors in the fruits market chain are local tax authority, local police, transporters and trade and industry office at district level.

g) Local tax authority: - it is a government organization responsible for collecting tax from licensed traders. Dispatch tax and annual income tax are collected. Without paying dispatch tax, smuggling of fruits product out of the locality is an illegal act.

h) Local police: - police play a role of inspecting the type of products that local wholesalers are transporting to big cities. Without police approval it is impossible for traders to distribute fruit products to regional and national markets.

i) Trade and industry office: - it is a government body which is responsible for giving trade license for those who wants to enter the fruits industries.

j) Transporters: - they are car owners facilitating the distribution of fruit products to big cities. Without the provision of car, distribution of fruit products to big cities in remote areas is unreliable.

\subsubsection{Major Channels for Fruit Products}

Based on the direction of flow and volume of fruits transacted, different marketing channels were identified. Most of the channels started from producers and endup in terminal markets of big cities through wholesalers.

\section{i) Market channels for banana}

\section{Channel I: Producer $\longrightarrow$ farmer traders $\longrightarrow$ local consumers}

This channel was the oldest and informal channel in the banana market chain. This channel linked producers to local consumers through farmer traders. Out of the total respondents, 22.70 percent of them took part in this channel. This channel was considered as informal because farmer raders do not have a license. Rather, they engaged in trading in seasons of excess production.

\section{Channel II: Producers $\longrightarrow$ Agents/ Brokers $\longrightarrow$ Local Wholesalers}

This channel linked producers to local wholesalers through agents /brokers. This channel was also identified as one of the oldest channels in the area. More than 40 percent of the respondents took part in this channel. Local wholesalers were in high preference of using brokers to purchase banana from producers. The good knowledge of brokers of their locality played an important role in saving wholesalers' time which would have been spent in search of marketable products.

Channel III: Producers $\longrightarrow$ Collectors'cooperatives $\longrightarrow$ Local Wholesalers

This channel was a newly introduced market channel in the area. This channel linked producers to local wholesalers through collector cooperatives. The proportion of sampled banana producers using this channel accounted for 16.82 percent.

Channel IV: Producers $\longrightarrow$ local wholesalers

This was a usual channel in the banana market chain. In this channel, producers directly sell their products to local wholesalers. The proportion of sampled banana producers using this direct channel accounted for 20.17 percent.

\section{ii) Market channel for Avocado}

Channel I: Producers $\longrightarrow$ farmer traders $\longrightarrow$ local consumers

This channel linked producers to local consumers through farmer traders. This was considered as the oldest and informal channel that prevails in the area. Out of the sampled avocado producers, 45.54 percent of them took part in this channel to distribute avocado products to the local market.

Channel II: Producers $\longrightarrow$ Agents /Brokers $\longrightarrow$ local wholesalers

In this channel producers linked to local wholesalers through agents/ brokers. This channel was practiced by 40.66 percent sampled producers. 


\section{Channel III: Producers $\longrightarrow$ Collectors}

It was an informal market channel in the avocado market chain. In peak seasons, collectors collect avocado products from producers and transport it to big cities to look for market opportunities for the harvested products. The biggest challenge in this channel was any marketing loss is borne by the producers. This implies this channel was the most risky channel for the producers. This channel was practiced by 13.8 percent of sampled producers.

\section{iii) Market channel for mango}

Channel I: Producers $\longrightarrow$ farmer traders $\longrightarrow$ local Consumers

This was the oldest and the most active market channel for mango in the area which was experienced by more than 65 percent of mango producers. Due to excess production and poor product quality traders were not interested to be engaged in mango trading.

Channel II: Producers $\longrightarrow$ Agents/ Brokers $\longrightarrow$ local wholesalers

This was also the oldest channel practiced by 35 percent of the producers. This channel linked producers and local wholesalers through brokers.

\subsubsection{Market Concentration Measure}

In this research, the concentration ratio of the biggest four firms were considered to determine the structure of the market. 40 traders in each specific fruit type were interviewed to understand the structure in the market.

Table 3. Concentration ratio

\begin{tabular}{lll}
\cline { 2 - 3 } Fruit type & $\mathbf{C R}_{\mathbf{4}}$ & Market Structure \\
\hline Banana & 86.76 & Strong oligopoly \\
Avocado & 91.67 & Strong oligopoly \\
Mango & 42.63 & Weak oligopoly \\
\hline
\end{tabular}

Source: Own survey (2016).

The table (table 3 ) shows that the market structure in the area showed different distinct feature for different fruit types. $\mathrm{CR}_{4}$ for banana was 86.76 percent which indicated that the market structure for banana was strong oligopoly. With regard to the structure of the avocado market, since the concentration ratio was 91.67 percent the structure was strong oligopoly. According to Severova, Kopecka, Svoboda, \& Brcak (2011), oligopoly can be defined as a market model of the imperfect competition type, assuming the existence of only a few companies in a sector or industry, from which atleast some have a significant market share and can therefore affect the production prices in the market. Therefore, a strong oligopoly market structure for banana and avocado implies that the concentration of market power on few big wholesalers in the locality. On the contrary, a less than 42.63 percent concentration ratio for mango indicated a weak oligopoly which, inturn, indicated a concentration of market power on few traders. Contrary to this finding, Nega et al. (2015) reported that the markets for Banana, Avocado, and Mango in Tembaro District were characterized by the prevalence of unconcentrated suppliers/ traders/ sellers.

\subsubsection{Barriers to Entry and Exit in the Fruits Market}

The ability of firms to enter an industry is an important structural factor that determines market performance (Perloff, 2007). The major causes of barriers to entry in the area were licensing and access to channels.

\section{i) Licensing}

A license is a permit given by the local government's trade and industry office for those who want to be engaged in fruits industries. Technically, the trader should have a warehouse and a weighing balance to get license. Institutionally, the trader should have a tax paying ID card (tin number). In addition, the licensee should have a dispatch letter from the local tax authority while distributing fruit products out of the locality. Without a dispatch letter from tax authority, any attempt to distribute fruit products out of the locality is illegal. Even agents should have an official delegation letter from the wholesaler to purchase fruit products from producers. Consistent with this finding, Desalegn \& Solomon (2014) reported that licensing was an entry barrier in a sense that licensed traders were strictly forbidden to perform other than the activity for which they were licensed.

ii) Access to channel

Few established local wholesalers control the access to channels of distribution in big cities of Ethiopia through 
long-standing relationships. This also has given the established local wholesalers an opportunity to distribute larger volumes of fruits products in big cities. This implies that inorder to get access to a new market, finding a trusted partner to work with is highly important. Therefore, access to channel in new markets is highly determined by established social relationship.

\subsubsection{Market Catchments (Market Points)}

Market catchments refer to the informal boundaries where market forces naturally limit the movement of a commodity (WFP, 2011). These areas are often functions of transaction costs, roads and infrastructure, international or sub-national borders and trade restrictions, trader networks, agricultural calendars, population density, language, etc (Ibid). According to the result of focus group discussion with traders, the common market catchments for traders were big cities like Jimma, Wolkite, Addis Ababa, Adama, Harar, Bahirdar, and Mekele. The participation of local traders in the aforementioned market catchments was highly influenced by the network they created in those cities. Since fruit products are highly perishable products, having a trusted trade partner in big cities is the most important criteria to do business. In this regard, the most reliable market point for the local traders was Jimma town. Most of FGD participants (traders) stated that they experienced defraud while trying to enter into a new market.

\subsubsection{Market Conduct}

Market conduct investigates the behaviors and rules that regulate the relationships between actors or how they engage with one another (WFP, 2011). Market conduct in this research indicated components like level of competition, the accepted standards in the market, transparency of transactions and terms of payment.

\section{A) Price Setting Mechanisms}

Fruit products are easily perishable by their very nature. Once the status of the fruit products reached maturity level, the producer's power to influence price is insignificant. In the study area, due to the existence of too many producers and few numbers of traders, producers were price takers. Consistent with this finding, Ayelech (2011) reported that farmers do not negotiate on price to sell their produce; indicating this large amount of producers are price takers.

B) Standard setting in the market

The existence of few numbers of traders in the market also gave a significant power for traders to set the standards of the fruit products. The FGD result revealed that good quality fruit products were determined by visual observation. After harvesting, the trader can reject the offer by the producer if the trader believed that it is a poor quality product; or low price will be offered to the producer for poor product quality. The lack of additional premium for good quality fruit products discouraged farmers from performing activities which can enhance product quality. Furthermore, constant price offered for fruit products irrespective of quality made farmers subservient to the needs of traders and agents.

\section{C) Sources and Transparency of Information}

Clear market information was highly crucial to create transparency and efficiency in the fruits markets. Out of the total respondents, 64.43 percent of them stated limited access to information as one of the bottlenecks in fruits marketing. This implies imperfect information was one of the causes for imperfect tmarket. There was no formal source of information for producers regarding pricing and overall market situation. Most producers relied on informal sources of information obtained from neighbors, brokers and traders. Regarding information transparency, there was no perfect exchange of information between producers and traders about product price in terminal markets. Therefore, in the absence of timely and reliable market information, market fails to bring economic efficiency. Consistent with this finding, Nega et al. (2015) reported that the majority of fruit producers lack adequate, timely and reliable market information in the study area.

\section{D) Terms of trade}

There was no formalized or regulated system in which effective exchange could take place between producers and traders. Regarding terms of payment, there was irregularity. Most of the time an exchange was being made on cash basis, but there were some room for post payment. More than 90 percent of producers practiced cash in hand system.On the contrary, all local traders stated that they received post payment. This implies that a deferral payment method was practiced between local traders and big city traders. The lack of formal and regulated trading system between actors in the chain typifies traditional marketing system where exchange took place based on trust and good social relationship. Since there is no legally binding agreement between actors in the chain, experiencing defraud is very common while entering into a new market. Consistent with this finding, 
Adugna (2009) and Nega et al. (2015) found that large proportion of the fruit producers practiced cash in hand system and take the price as soon as they sell the fruits.

\subsubsection{Market Performance}

Market performance refers to the impact of structure and conduct as measured in terms of variables such as prices, marketing margins, and volume of output. The gross \& netmarketing margins and producer's share in the final price for different marketing channels in banana, avocado and mango marketing are presented in Tables 4, 5 and 6.

\subsubsection{Performance of Banana Market Chain}

The performance of banana market chain was calculated by taking Jimma town as a common market catchment for all traders. This happened because of its accessibility to all local traders as compared to other catchment areas.

In terms of TGMM, total gross marketing margin in channel II and channel IV were 83.33 percent for each respective channel. TGMM in channel III was 85.33 percent. Channel I accounted for 60 percent of TGMM. According to Cramer \& Jenson (1982), wider marketing margins in all channels were good indicators of the existence of imperfect markets for banana in the study area.

In the final price for the different channels of the banana marketing system, producers captured 16.67 percent of the final price in channel II linking producers and wholesalers through brokers; followed by 16.67 percent in channel IV linking producers directly to wholesalers. 14.67 percent of the final price was captured in channel III where producers and wholesalers linked through collectors. The highest producers' share was 40 percent in channel I where banana flowed from producers to local consumers through farmer traders. High TGMM diminished the share of producer's in final price.

In terms of carrying large volumes of banana, 89.48 percent of sales volumes accounted for channel II, followed by 8.21 percent for channel IV, 2.31 percent for channel III, and the remaining $0.001 \%$ of sales volumes accounted for farmer traders. This implies that channel II is more efficient in terms of distributing large volumes of sales. The FGD result revealed that wholesalers preferred to be linked with producers through brokers (channel II). Brokers' knowledge of the locality made this channel highly preferable for wholesalers in providing information about marketable products which in turn saved wholesalers' time.

Table 4. Performance of the banana market chain

\begin{tabular}{|c|c|c|c|c|c|c|c|c|c|}
\hline \multirow{2}{*}{$\begin{array}{l}\text { Marketingchan } \\
\text { nel }\end{array}$} & \multirow[t]{2}{*}{ Items } & \multicolumn{8}{|c|}{ Marketactors } \\
\hline & & $\begin{array}{l}\text { Produce } \\
\text { rs }\end{array}$ & $\begin{array}{l}\text { Broke } \\
\text { rs }\end{array}$ & $\begin{array}{l}\text { Farmertrade } \\
\text { rs }\end{array}$ & $\begin{array}{l}\text { Collecto } \\
\text { rs }\end{array}$ & $\begin{array}{l}\text { Wholesale } \\
\text { rs }\end{array}$ & $\begin{array}{l}\text { Bigwholesal } \\
\text { ers }\end{array}$ & $\begin{array}{l}\text { Retaile } \\
\text { rs }\end{array}$ & $\begin{array}{l}\text { Consume } \\
\text { rs }\end{array}$ \\
\hline \multirow[t]{4}{*}{ Channel1 } & $\begin{array}{l}\text { Sellingprice/bun } \\
\text { ch }\end{array}$ & 20 & & 50 & & & & & \\
\hline & TGMM & & & $60 \%$ & & & & & \\
\hline & GMMp & & & $40 \%$ & & & & & \\
\hline & Salesvolume & & & $.001 \%$ & & & & & \\
\hline \multirow[t]{6}{*}{ Channel2 } & $\begin{array}{l}\text { Sellingprice/bun } \\
\text { ch }\end{array}$ & 25 & 28 & & & 50 & 80 & 150 & 150 \\
\hline & TGMM & & 10.71 & & & $50 \%$ & $68.75 \%$ & $83.33 \%$ & $83.33 \%$ \\
\hline & & & $\%$ & & & & & & \\
\hline & GMMp & & 89.29 & & & $50 \%$ & $31.25 \%$ & $16.67 \%$ & $16.67 \%$ \\
\hline & & & $\%$ & & & & & & \\
\hline & Salesvolume & & & & & & & & $2.31 \%$ \\
\hline \multirow[t]{4}{*}{ Channel3 } & $\begin{array}{l}\text { Sellingprice/bun } \\
\text { ch }\end{array}$ & 22 & & & 30 & 50 & 80 & 150 & 150 \\
\hline & TGMM & & & & $26.67 \%$ & $56 \%$ & $72.50 \%$ & $85.33 \%$ & $85.33 \%$ \\
\hline & GMMp & & & & $73.33 \%$ & $44 \%$ & $27.50 \%$ & $14.67 \%$ & $14.67 \%$ \\
\hline & Salesvolume & & & & & & & & $89.48 \%$ \\
\hline \multirow[t]{4}{*}{ Channel4 } & $\begin{array}{l}\text { Sellingprice/bun } \\
\text { ch }\end{array}$ & 25 & & & & 50 & 80 & 150 & 150 \\
\hline & TGMM & & & & & $50 \%$ & $68.75 \%$ & $83.33 \%$ & $83.33 \%$ \\
\hline & GMMp & & & & & $50 \%$ & $31.25 \%$ & $16.67 \%$ & $16.67 \%$ \\
\hline & Salesvolume & & & & & & & & $8.21 \%$ \\
\hline
\end{tabular}

Source: Own Computation (2016). 


\subsubsection{Performance of Avocado Market Chain}

In analyzing market chain for avocado, the common market catchment taken for the sake of this analysis was Addis Ababa city. All traders highly participated in avocado trading at a market in Addis Ababa. Hence, price information at Addis Ababa was used to calculate TGMM.

In terms of total gross marketing margin, TGMM was highest in channel II and III (90\%). Channel I captured the lowest TGMM which accounted for 66.67 percent. According to Cramer \& Jenson (1982), the wider marketing margins in all of the three channels were good indicators of the existence of imperfect markets for avocado in the study area.

Regarding share of producers of final price for avocado market chain, producers captured 10 percent of the final price in channel II and channel III, followed by 66.67 percent in channel I. In terms of volume, channel II, which linked producers to wholesalers through brokers, covered 82.84 percent of total sales volumes, followed by 14.71 percent of sales volumes in channel II, and the remaining $0.02 \%$ of sales volumes in channel I. This implies channel II was more efficient in terms of distributing large volumes of quantities to terminal markets in big cities. According to FGD result with collectors and producers, a relatively higher GMMp in channel I was not supported by high volumes of sales. In addition, in channel III all costs incurred (post - harvesting losses) were born by producers which made this channel inefficient in terms of distributing large volumes of sales. Like the banana market chain, channel II which linked producers to local wholesalers through brokers was preferable channel in terms of ease access to information through brokers to local wholesalers.

Table 5. Performance of the avocado market chain

\begin{tabular}{|c|c|c|c|c|c|c|c|c|c|}
\hline \multirow{2}{*}{$\begin{array}{l}\text { Marketingchan } \\
\text { nel }\end{array}$} & \multirow[t]{2}{*}{ Items } & \multicolumn{8}{|c|}{ Market actors for Avocado } \\
\hline & & $\begin{array}{l}\text { Produce } \\
\text { rs }\end{array}$ & $\begin{array}{l}\text { Broke } \\
\text { rs }\end{array}$ & $\begin{array}{l}\text { Farmertrade } \\
\text { rs }\end{array}$ & $\begin{array}{l}\text { Collecto } \\
\text { rs }\end{array}$ & $\begin{array}{l}\text { localwholesal } \\
\text { ers }\end{array}$ & $\begin{array}{l}\text { Bigwholesal } \\
\text { ers }\end{array}$ & $\begin{array}{l}\text { Retaile } \\
\text { rs }\end{array}$ & $\begin{array}{l}\text { Consume } \\
\text { rs }\end{array}$ \\
\hline \multirow[t]{4}{*}{ Channel1 } & $\begin{array}{l}\text { Sellingprice/ } \\
\text { qt }\end{array}$ & 200 & & 300 & & & & & \\
\hline & GMMp & & & $66.67 \%$ & & & & & \\
\hline & TGMM & & & $33.33 \%$ & & & & & \\
\hline & Salesvolume & & & $.02 \%$ & & & & & \\
\hline \multirow[t]{4}{*}{ Channel2 } & $\begin{array}{l}\text { Sellingprice/ } \\
\text { qt }\end{array}$ & 200 & 250 & & & 600 & 1000 & 2000 & 2000 \\
\hline & GMMp & & $80 \%$ & & & $33.33 \%$ & $20 \%$ & $10 \%$ & $10 \%$ \\
\hline & TGMM & & $20 \%$ & & & $66.67 \%$ & $80 \%$ & $90 \%$ & $90 \%$ \\
\hline & Salesvolume & & & & & $82.84 \%$ & & & \\
\hline \multirow[t]{4}{*}{ Channel3 } & $\begin{array}{l}\text { Sellingprice/ } \\
\text { qt }\end{array}$ & 200 & & & 500 & & 1000 & 2000 & 2000 \\
\hline & GMMp & & & & $40 \%$ & & $20 \%$ & $10 \%$ & $10 \%$ \\
\hline & TGMM & & & & $60 \%$ & & $80 \%$ & $90 \%$ & $90 \%$ \\
\hline & Salesvolume & & & & $14.71 \%$ & & & & \\
\hline
\end{tabular}

Source: Own Computation (2016).

\subsubsection{Performance of Mango Market Chain}

In the mango marketing system, the common market catchment used for this analysis was Addis Ababacity.

Table 6. Performance of the mango market chain

\begin{tabular}{|c|c|c|c|c|c|c|c|c|}
\hline \multirow[t]{2}{*}{ Marketingchannel } & \multirow[t]{2}{*}{ Items } & \multicolumn{7}{|c|}{ MarketactorsforMango } \\
\hline & & Producers & Brokers & Farmertraders & wholesalers & Bigwholesalers & Retailers & Consumers \\
\hline \multirow[t]{4}{*}{ ChannelI } & Sellingprice/qt & 120 & & 200 & & & & \\
\hline & GMMp & & & $60 \%$ & & & & \\
\hline & TGMM & & & $40 \%$ & & & & \\
\hline & Salesvolumes & & & 3.11 & & & & \\
\hline \multirow[t]{4}{*}{ ChannelII } & Sellingprice/qt & 150 & 200 & & 500 & 1000 & 2000 & 2000 \\
\hline & GMMp & & $75 \%$ & & $30 \%$ & $15 \%$ & $7.5 \%$ & $7.5 \%$ \\
\hline & TGMM & & $25 \%$ & & $70 \%$ & $85 \%$ & $92.5 \%$ & $92.5 \%$ \\
\hline & Salesvolumes & & & & 96.89 & & & \\
\hline
\end{tabular}

Source: Own Computation (2016). 
In terms of TGMM, channel II captured more than 92 percent of TGMM and the remaining $7.5 \%$ of TGMM was captured in channel I. Regarding the final price for the two channels of mango marketing system, producers captured 60 percent of the final price in channel I linking producers and consumers through farmer traders and $7.5 \%$ of the final price share in channel II linking producers to wholesalers through brokers. However, inchannel I, small volumes $(3.11 \%)$ of mango were distributed to the market as compared to channel II which covered 96.89 percent of sales volumes. This clearly indicates that a link created through brokers was highly preferred in terms of absorbing large volumes of products. However, the TGMM in channel II pointed out that the market was imperfect.

\subsection{Challenges of Fruits Marketing}

\section{i) Seasonality}

Seasonality is another factor affecting fruits marketing in the area.More than 89.93 percent of the respondents stated that seasonal price fluctuation was the major problem in fruits marketing. During peak supply period, price declined. In peak seasons, the perishability of the products does not give enough time for producers to look for alternative market opportunities. Thus, producers accept low price offered in peak seasons to avoid massive loss of profits. The FGD result revealed that price declined by more than 15 percent in peak seasons. This implies that when there is excess supply of fruits, price declines. Therefore, seasonal price fluctuation was common in the study area implying that supply and price moves in opposite direction.

\section{ii) Few number of big traders}

There were many producers but very few big traders in the area. The large volumes of outputs produced in the area must be absorbed by high demand in big cities. More than 66.77 percent of the respondents stated that limited access to market was among the challenges of fruits marketing in the area. The participation of big traders in the fruits industries is highly important in bringing better opportunity for producers. However, the existence of few big traders in the fruits industries limited producers' access to more efficient market channel.

\section{iii) Lack of organized market center}

In the FGD, it was revealed that lack of organized market center was one of the basic problems for the existence of imperfect competition in the area. Getting better incentives in terminal markets depend on the quality of the produce to be offered in those markets. However, due to absence of market center in which good product quality is inspected and standardized, producers and traders failed to receive their fair share from the market in big cities.

\section{iv) Brokers' interference}

The main role of brokers/ agents in the fruits markets was providing information about price and output both for producers and traders. As a result, they were considered as the most reliable partners for traders in making deals with producers. Brokers created collusion in the fruits markets in terms of geographic dispersion to avoid unnecessary competition. This collusion helped them to monopolize a certain geographic area. So, without brokers, it is hardly possible to create direct link between producers and traders in the study area. More than 52.35 percent percent of total respondents stated that broker's unwelcomed interference was one of the major problems in fruit marketing.

\section{Conclusion and Recommendation}

The result of this study revealed that different market actors were involved in the fruits market chain. The actors were classified as primary actors and secondary actors based on the role they played in the markets. Producers, farmer traders, agents/ brokers, collector cooperatives, and wholesalers were identified as primary actors. Whereas, local tax authority, local police, transporters and district Trade Industry office were identified as secondary actors because of their indirect influence in facilitating the fruits market. The market structures of fruits show non-competitive nature characterized by barriers to entry and exit. The market concentration ratios ranging from 42 percent up to 91.67 percent were indicators of oligopoly market structure. The existence of few big-traders in the market gave market power for traders in deciding output price and setting product quality standard. The TGMM indicated that the markets for banana, avocado, and mango were imperfect markets. However, the most efficient fruits market channel in the area was the one that links producers to wholesalers through brokers. Brokers' good knowledge of the locality made this channel a preferable channel to distribute large volumes of fruit products to terminal markets in big cities. However, seasonal price fluctuation, the existence of few big traders, limited access to information, lack of organized market center, and brokers' interference mainly affected the performance of fruits market in the study area. Consequently, the fruits marketing in the study area were found imperfect. Therefore, attention has to be given to alleviate the problems 
so as to improve the performance of the fruits market.

\section{Acknowledgement}

We would like to acknowledge Mizan-Tepi University for funding this research.

\section{References}

Abbot, J. C., \& Makeham, J. P. (1981). Agricultural Economics and Marketing in the Tropics (p. 58). Rome: Wing Tai Cheung Printing Co. Ltd.

Adugna, G. (2009). Analysis of Fruit and Vegetable Market Chains in Alamata: The Case of Onion, Tomato and Papaya (p. 114). Southern Zone of Tigray.

Ayelech, T. (2011). Market Chain Analysis of Fruits for Gomma Woreda, Jimma Zone, Oromia National Regional State.

Cramer, G. L., \& Jensen, W. (1982). Agricultural Economics and Agribusiness (2nd ed.). New York: McGraw Hill Book Company.

Dessalegn, G., \& Solomon, K. (2014). Evaluating Coffee Market Structure and Conduct in Bench Maji Zone, SouthWest Ethiopia. Journal of Agricultural Economics, Extension and Rural Development, 2(5), 156-163.

Edwards, S., Allen, A. J., \& Saleem, S. (2005). Market Structure Conduct Performance (SCP) Hypothes is revisited using Stochastic Frontier Efficiency Analysis.

Ethiopian Investment Agency (EIA). (2012). Investment Opportunity Profile for the Production of Fruits and vegetables in Ethiopia.

Food and Agriculture Organization (FAO). (2005). Market Segmentation of Major Avocado Markets, Sugar and Beverages Group Raw Materials, Tropical and Horticultural Products Service Commodities and Trade Division.

Humble, S., \& Reneby, A. (2014). Post-harvest losses in fruit supply chains-A case study of mango and avocado in Ethiopia.

ILRI. (2011). Fruits-A synthesis of IPMS value-chain development experiences. ILRI, Nairobi.

Meijer, P. W. M. (1994). The Function of Maize Market in Benin (pp. 11-32). Benin: Bert Broundjin.

Mendoza, M., \& Rosegant, M. (1995). Pricing conduct of spatially differentiated markets. Prices, Products, and People (pp. 343-356). International Potato Center, Lima, Peru.

National Bank of Ethiopia (NBE). (2013). BIRRITU, No. 115.

Nega, M., Teshale, W., \& Zebene, A, (2015). Market Chain Analysis of Agro-forestry Products: The Case of Fruit at Tembaro District, Kembata Tembaro Zone South Ethiopia. International Journal of Business and Economics Research, 4(4), 201-216.https://doi.org/10.11648/j.ijber.20150404.13

Perloff, J. M., Karp, L. S., \& Golan, A. (2007). Estimating Market Power and Strategies. Cambridge: Cambridge University Press. NewYork, U.S.A. https://doi.org/10.1017/cbo9780511753985

Severova, L., Kopecka, L., Svoboda, R., \& Brcak, J. (2011-12). Oligopoly competition in the market with food products. Agric. Econ-Czech, 57, 2011(12), 580-588.

Simegnew, T. (2012). The Brokerage Institutions and Smallholder Market Linkages in Marketing of Horticultural Crops in Fogera Woreda, South Gondar, Ethiopia.

SNNP Investment office. (2007). Investment Opportunities in Southern Nations, Nationalities and People's Regional State.

Stead, R., Curwen, P., \& Lawler, K. (1996). Industrial Economics: Theory, Applications and Policy.UK: McGraw-Hill International LTD.

Takele, H. (2014). Review of Mango Value Chain in Ethiopia. Journal of Biology, Agriculture andHealthcare, $4(25)$.

The Second Growth and Transformation Plan (GTPII). (2015). National Planning Commission, September 2015, Addis Ababa, Ethiopia.

Thomas, C. R., \& Maurice, S. C. (2011). Managerial Economics: Foundations of Business Analysis and Strategy (10th ed.). NewYork: John Wiley and Sons.

Tomek, W. G., \& Robinson, K. L. (1990). Agricultural Product Prices (3rd ed., pp. 107-108). New York: Cornell 
University Press.

Uhl, J. N., \& Kohi, R. L. (1985). Marketing of Agricultural Product (5th ed., p. 624). Collier Macmillan, USA.

World Bank Group. (2006). Ethiopia: Developing Competitive Value Chain.

World Bank. (2004). Poverty Reduction and Economic Management, Country Department for Ethiopia: Opportunities and Challenges for Developing High-value Agricultural exports in Ethiopia, Africa region, background report, April 9, 2004.

World Food Program (WFP). (2011). Market Analysis Framework. Tools and Applications for Food Security Analysis and Decision-Making.

\section{Copyrights}

Copyright for this article is retained by the author, with first publication rights granted to the journal.

This is an open-access article distributed under the terms and conditions of the Creative Commons Attribution license (http://creativecommons.org/licenses/by/4.0/). 